\title{
FRUITING PHENOLOGY OF A SCRUB FOREST IN THIRUPORUR, EASTERN GHATS, INDIA
}

\author{
R. Aruna ${ }^{1^{*}}, \mathrm{P}$. Balasubramanian $^{2}$ \\ ${ }^{1}$ Assistant Professor, PG and Research Department of Botany, Thiagarajar College, Madurai, \\ India. \\ ${ }^{2}$ Principal Scientist, Division of Landscape Ecology, Salim Ali Centre for Ornithology and Natural \\ History, Anaikatty P.O, Coimbatore, India. \\ E-mail address: arsbot@gmail.com
}

Keywords: Fruiting phenology, Scrub forest, Eastern Ghats, India

\begin{abstract}
This paper describes the fruiting phenology of 110 individuals of woody species belonging to 22 taxa ( 21 species, 1 variety) belonging to 15 families including 2 species of figs in a scrub forest, Thiruporur, Eastern Ghats. Fruiting peak was observed during July 2009 with 11 species in fruiting, a dip was observed during March 2009 where only 2 species were in fruiting. Season wise fruiting peak was observed during South-west and North-east Monsoon while the dip was during summer.
\end{abstract}

\section{INTRODUCTION}

Phenology is the study of relationship between climatic factors and periodic phenomena in organisms. Periodic behaviour of plants in tropical environments has received much attention in recent years. Tropical forests with their high level of species diversity, display phenological events such as leaf drop, leaf flushing, flowering and fruiting, etc. in relation to time and space [1]. Study of such events is useful in evolving proper management strategy as well as better understanding of natural forest regeneration potential and community level interactions [2]. The study of plant phenology provides knowledge about the pattern of plant growth and development as well as the effects of environment and selective pressures on flowering and fruiting behavior [3].

In India the phenology of tree species has been studied in the subtropical forests in northeastern region $[4,5]$. Knowledge of fruiting phenology is of central importance for conservation management generally, but is of special value in tropical forests which support a diversity of fruitdependent species [6]. The fruiting phenology of scrub forest in Eastern Ghats region is less understood. The present work aims to document the phenological diversity of fruiting of scrub forest in Eastern Ghats.

\section{STUDY AREA}

Study on scrub forest observation was made in Thiruporur, Kancheepuram district in Eastern Ghats. Kancheepuram district is situated on the northern East Coast of Tamil Nadu and is adjacent by Bay of Bengal and Chennai city and is bounded in the west by Vellore and Thiruvannamalai district, in the north by Thiruvallur district and Chennai district, in the south by Villuppuram district in the east by Bay of Bengal. It lies between $11^{\circ} 00^{\prime}$ to $12^{\circ} 00^{\prime}$ North latitudes and $77^{\circ} 28^{\prime}$ to $78^{\circ} 50^{\prime}$ East longitudes. The district has a total geographical area of 4, 43,210 hectares and coastline of 57 Kms. There are only a few hills of considerable elevation in the district. The southern part of Maduranthakam taluk contains small hills. The total forest area in the district is 23,586 hectares, it spread interior regions and around the district.

\section{METHODOLOGY}

A total of 110 individuals of woody species belonging to 22 taxa ( 21 species, 1 variety) belonging to 15 families, including 2 species of figs were marked with aluminum tags and observed 
for phenology (Table 1). The phenology of fruit production was observed fornight to assess the periodicity of fruiting. During the visit, percentage of fruit in the canopy was visually estimated and then the estimate was divided into percentage of ripe and unripe fruit, based primarily on colour changes indicating ripeness (Anggraini et al., 2000). The families studied were Anacardiaceae, Apocynaceae, Arecaceae, Cordiaceae, Ebenaceae, Euphorbiaceae, Loganiaceae, Meliaceae, Memecylaceae, Moraceae, Myrtaceae, Rhamnaceae, Rubiaceae, Rutaceae and Tiliaceae. Phenological observations were carried out for a continuous period of one year in the scrub forest.

\section{RESULTS}

A fruiting peak was observed during July 2009 with 11 species in fruiting. Species that fruited during July include Azadirachta indica, Diospyros ovalifolia, Ficus benghalensis, Ficus religiosa, Lannea coromandelica, Diospyros ferrea var buxifolia, Manilkara hexandra, Melia azedarach, Memecylon umbellatum, Strychnos potatorum and Syzygium cumini. A dip was observed during March 2009 where only 2 species had fruits, viz. Carissa spinarum and Ficus benghalensis (Figure 1). The fruiting peak was noticed during July where 52 individuals (34.6\%) were fruiting out of 150 individuals. A dip was noticed in March with 8 individuals (5.3\%) in fruits (Figure 2).

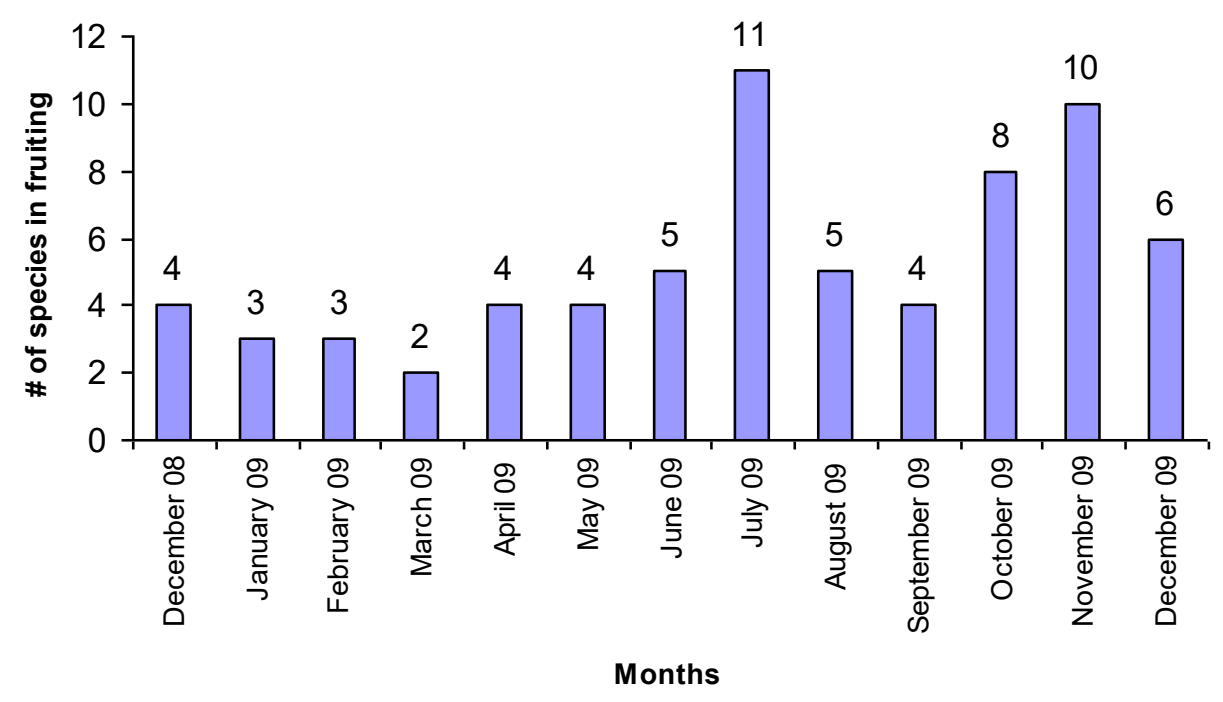

Fig.1. Phenology of fleshy fruited plants in the tropical mixed dry deciduous forest. (\# of species in fruiting) 


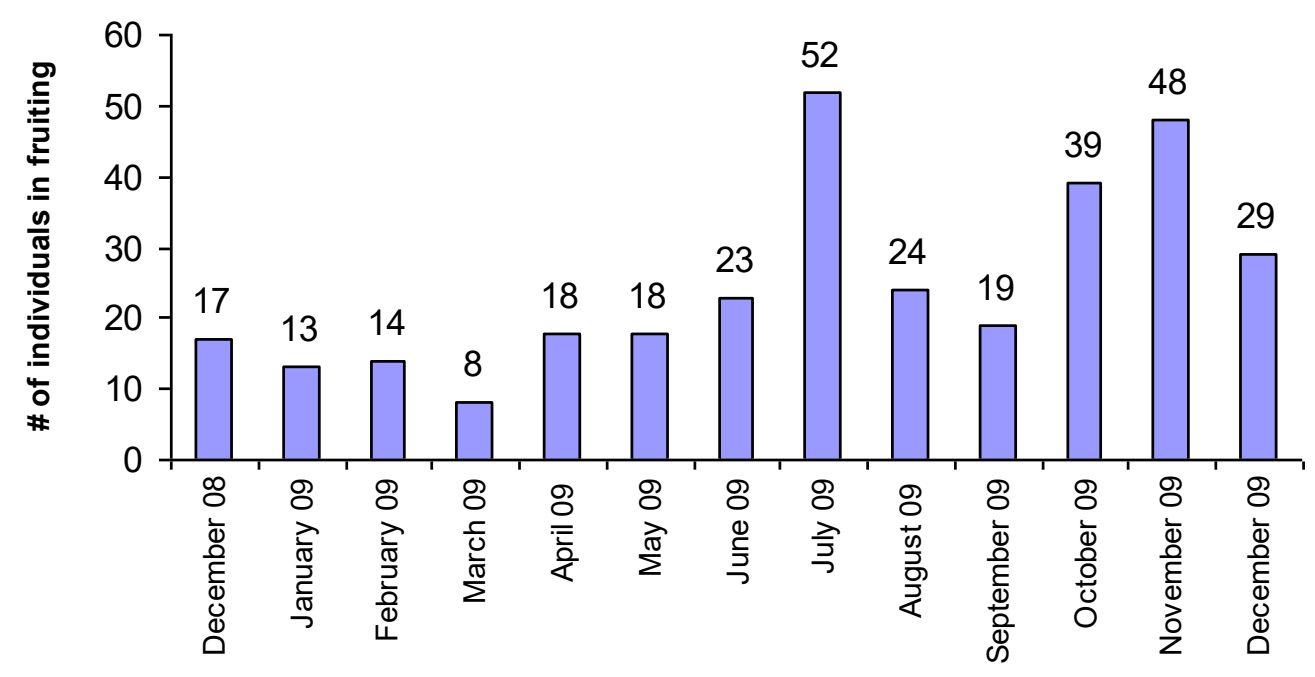

\section{Months}

Fig. 2. Phenology of fleshy fruited plants in the tropical mixed dry deciduous forest. (\# of individuals in fruiting)

The phenology is discussed with regard to four seasons namely, Summer (March-May), South-west Monsoon (June-August), North-east Monsoon (September-November) and Post Monsoon (December-February). A peak was observed in South-west and North-east Monsoon and a dip in summer (Table 1). Fruiting schedule of fleshy fruited woody plants of the study area are shown in Table 2.

Table 1. Fruiting phenology of woody plants in different seasons, scrub forest.

\begin{tabular}{|l|c|c|c|}
\hline \multirow{2}{*}{\multicolumn{1}{c|}{ Season }} & \multicolumn{3}{|c|}{ \# species in fruiting } \\
\cline { 2 - 4 } & Trees & Shrubs & Total \\
\hline South-west monsoon & 10 & 2 & 12 \\
\hline Post monsoon & 2 & 5 & 7 \\
\hline Summer & 6 & 0 & 6 \\
\hline North-east monsoon & 3 & 9 & 12 \\
\hline
\end{tabular}


Table 2. Fruiting schedule of fleshy fruited species in scrub forest

\begin{tabular}{|c|l|c|c|c|c|}
\hline S.No. & Name of the plant species & Summer & $\begin{array}{c}\text { South-West } \\
\text { Monsoon }\end{array}$ & $\begin{array}{c}\text { North-East } \\
\text { Monsoon }\end{array}$ & $\begin{array}{c}\text { Post- } \\
\text { Monsoon }\end{array}$ \\
\hline 1 & Azadirachta indica & $\sqrt{ }$ & $\sqrt{ }$ & & \\
\hline 2 & Benkara malabarica & & & $\sqrt{ }$ & $\sqrt{ }$ \\
\hline 3 & Canthium dicoccum & & & $\sqrt{ }$ & $\sqrt{ }$ \\
\hline 4 & Carissa spinarum & & & $\sqrt{ }$ & \\
\hline 5 & $\begin{array}{l}\text { Carissa spinarum var } \\
\text { microphylla }\end{array}$ & & $\sqrt{ }$ & $\sqrt{ }$ & \\
\hline 6 & Carmona retusa & & $\sqrt{ }$ & $\sqrt{ }$ \\
\hline 7 & $\begin{array}{l}\text { Diospyros ferrea } \text { var } \\
\text { buxifolia }\end{array}$ & & $\sqrt{ }$ & $\sqrt{ }$ & \\
\hline 8 & Diospyros ovalifolia & $\sqrt{ }$ & $\sqrt{ }$ & $\sqrt{ }$ & \\
\hline 9 & Ficus benghalensis & $\sqrt{ }$ & $\sqrt{ }$ & $\sqrt{ }$ \\
\hline 10 & Ficus religiosa & & $\sqrt{ }$ & \\
\hline 11 & Fluggea virosa & & $\sqrt{ }$ & \\
\hline 12 & Glycosmis cymosa & & $\sqrt{ }$ & & \\
\hline 13 & Grewia hirsute & & $\sqrt{ }$ & \\
\hline 14 & Lannea coromandelica & $\sqrt{ }$ & & & \\
\hline 15 & Manilkara hexandra & & & & \\
\hline 16 & Melia azedarach & & & & \\
\hline 17 & Memecylon umbellatum & & & & \\
\hline 18 & Phoenix pusilla & & & & \\
\hline 19 & Scutia myrtina & & & & \\
\hline 20 & Strychnos potatorum & & & & \\
\hline 21 & Syzygium cumini & & & & \\
\hline 22 & Ziziphus oenoplia & & & & \\
\hline
\end{tabular}

\section{DISCUSSION}

Fruiting peak was recorded during both South-west and North-east monsoon with 12 species each fruiting. [7] in a South African Coastal forest reported the fruiting peak (August-October) (March-May). Periods of fruit scarcity were found during the dry season in July and August and during the rainy season in November and December. In the tropics and subtropics, the production of fleshy fruits tends to be highest early in the wet season $[8,9]$.

Fruiting peak during wet season was reported from several tropical forests [10, 11]. [12] reported fruiting peak during September in subtropical forest at Manipur which coincides with the present study.[13] in Coromandel Coast of India in their phenological studies observed that fruiting during dry season was less when compared to wet season. [14] observed peak of fleshy fruits during post monsoon season, in the tropical dry evergreen forest. [15] observed a peak in fruiting during the South-west monsoon (21 species) and a dip during Post monsoon ( 9 species) in a tropical mixed dry deciduous forest, Western Ghats. 
In the present study, Ficus benghalensis fruited during March- November; Ficus religiosa fruited during June - August. A study in the moist deciduous forest in Simlipal Biosphere Reserve [16] indicates that Ficus benghalensis bore fruits during April - June and December - February; Ficus religiosa fruited during June to October. In another study at a dry deciduous forest, Satlasana range forest, Gujarat [17] states that Ficus benghalensis was in fruiting during April, May and June, Ficus religiosa during April, October.

In contrast, Ficus racemosa and Ficus religiosa were found to be available year around in a deciduous forest and evergreen forest, Western Ghats [18]. According to a study [19] Ficus benghalensis bore fruits during September-November, Ficus religiosa during April - May at Goalpara, Assam. In some seasonal tropical forests, the number of animal-dispersed species peaks during the rainy season $[20,21]$. In aseasonal tropical forests, such as those in Malaysia, fruiting occurs throughout the year; usually without defined peaks in fruit or frugivores abundance [22, 23].

In the present study, it was observed that summer had a dip with 6 species in fruits, but Ficus benghalensis was fruiting during this period of fruit scarcity and supported a large number of avian frugivores which clearly shows that Ficus is a keystone species in this study area. [24] reported peak fruiting in figs coincided with peak in non-fig fruiting in a wet evergreen forest site in Western Ghats which coincides with the present study in Eastern Ghats. Carmona retusa, Glycosmis cymosa and Ziziphus oenoplia were seasonal as the fruiting occurred only during one season i.e, South-west Monsoon, North-east Monsoon, Post-Monsoon respectively. Some species fruited during two or three seasons Ficus benghalensis bore fruits in three seasons.

\section{Acknowledgements}

We thank Dr. P.A. Azeez Director, Salim Ali Centre for Ornithology and Natural History for the encouragement. We thank the Tamilnadu forest department who provided permission to carry out the project; we also thank the field staff of forest department at Thiruporur who helped us in the field work. Author R.Aruna would like to dedicate this research article to Dr.A.P.J.Abdul Kalam for his inspiration.

\section{References}

[1] Singh J.S, Singh V.K., Curr Sc. 63(1992) 684.

[2] Fox J.E.D, For Ecol \& Manag. 1(1976) 37

[3] Zhang G, Song Q, Yang D., Biotrop. 38 (2006) 334.

[4] Boojh R, Ramakrishnan P.S., Geo Eco Trop. 5(1981) 189.

[5] Kikim A, Yadava P.S., Trop Ecol. 42(2001) 269.

[6] Fenner M. Perspectives in Plant Ecology, Evolution and Systematics. (1998) 78.

[7] Bleher B, Potgieter C. J, Johnson D. N, Bohning-gaese K., J of Trop Ecol 19(2003) 375.

[8] Lieberman 1982, J of Eco 70, 791-806.

[9] Guevarad, E., Lampe, M., Bergeron, Y., McNeil, R. and Leduc, A. 1992. Biotropica. 24:6476.

[10] Murali, K.S. 1992. Phd thesis. Centre for Ecological Sciences, Indian Institute of Science, Bangalore.

[11] Sundarapandian, S.M., Chanderasekaran, S., and Swamy,P.S. 2005. Curr. Sci., 88: 805-810.

[12] Kikim, A., and Yadava. P.S. (2001) Trop Ecol., 42(2): 269-276.

[13] Selwyn, M., and Parthasarathy, N. 2007.

[14] Balasubramanian, P. and Bole, P. V. (1993). JBNHS.,.90(2):163-177. 
[15] Aruna.R. 2013.(Ph.D Thesis).Salim Ali centre for Ornithology and Natural History, Bharathiar University.

[16] Mishra, R.K., Upadhyay, V.P., Mohapatra, S.B. and Mohanty, R.C. 2006. Lyon., 11(1): 517.

[17] Desai, P. B., and Patel, N. K. 2010. Life sciences Leaflets 3:41-46.

[18] Patel, A. 1997. Journal of Tropical Ecology, 13: 681-695.

[19] Namita, N. 2012. Indian Journal of Fundamental and Applied Life Sciences. 2(1): 102-104.

[20] Milton, K. 1982. In Leigh, E. G. Rand, A. S. and Windsor, D. M. (Eds.). The ecology of a tropical forest. Smithsonian Institution Press, Washington, DC. 273-289

[21] Stocker, G. C. and Irvine, A. K. 1983. Biotropica. 65: 609-617.

[22] Putz, F.E. 1979. Malay For 42:1-24.

[23] Rathcke, B and Lacey, E. P. 1985. Ann. Rev. Ecol. Syt., 16: 179- 214.

[24] Patel, A. 1997. Journal of Tropical Ecology, 13: 681-695. 